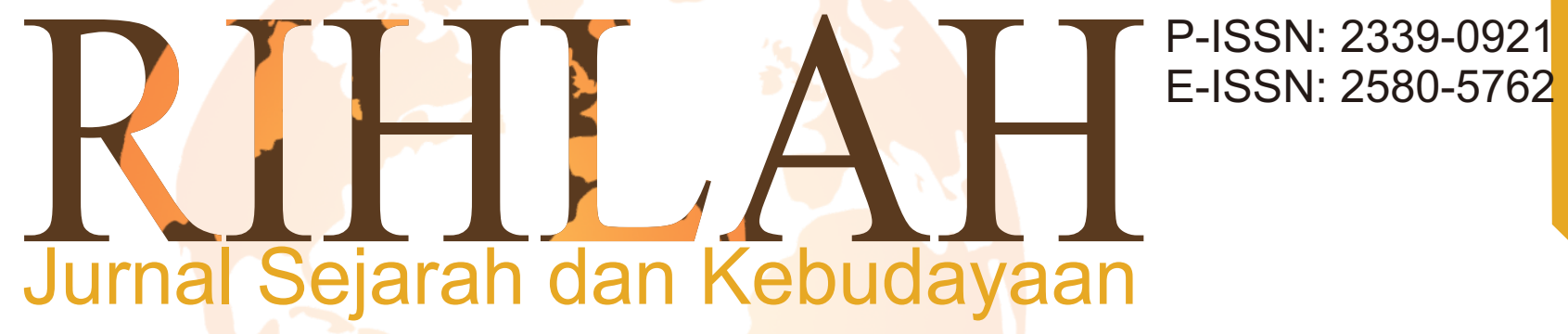

Sejarah Diaspora Suku Bugis-Makassar di Kalimantan Tengah Suryanti, Ihsan Mz, ST. Rahmah

Kearifan Lokal Handep Masyarakat Dayak: Perspektif Cendekiawan Muslim Dayak di IAIN Palangka Raya Muhammad Husni

Tradisi Masyarakat Islam Melayu Jambi: Perspektif Pierre Bordieau Aliyas, Benny Agusti Putra

Tradisi Mappande Sasi' pada Masyarakat Tangnga-tangnga Kabupaten Polewali Mandar (Unsur Budaya Islam) Nurannisa, Ahmad M. Sewang, Wahyuddin G

Implementasi Ritual Addinging-dinging pada Masyarakat Modern di Tambung Batua Gowa: Tinjauan Sosio-Kultural)

Mastanning, Khadijah Tahir, Abdullah Renre

Iran pada Masa Reza Syah 1925-1941

Faiz Nasrullah

Penyebaran Pendidikan Islam di Buol Abad XX M.

Muhammad Nur Ichsan Azis, Salmin Djakaria 


\section{RIHLAH}

\section{Jurnal Sejarah dan Kebudayaan}

\begin{tabular}{|l|l|}
\hline Editor in Chief & $:$ Dr. Rahmat, M.Pd. \\
\hline Managing Editor & $:$ Nurlidiawati, S.Ag., M.Pd. \\
\hline Editors & $:$ Prof. Dr. Mardan, M.Ag. \\
$:$ Dr. Zaenal Abidin, SS., M.Hi. \\
$:$ Dr. Lydia Megawati, M.Hum. \\
$:$ Mastanning, M.Hum. \\
$:$ Aksa, M.Pd. \\
$:$ Chaerul Munzir, M.Hum. \\
$:$ Muhammad Arif, M.Hum. \\
$:$ Misbahuddin, M.Hum. (IAIN Ternate) \\
\hline Editorial Board & $:$ Dr. Syamhari, M.Pd. \\
$:$ Dra. Hj. Surayah, M.Pd. \\
$:$ Nur Ahsan Syakur, S.Ag., M.Si. \\
$:$ Chusnul Chatima Asmad, S.S., M.Hum. \\
$:$ Saepuddin, M.Ag. (STAIN Riau) \\
$:$ Iqbal, M.Hum. \\
$:$ Miftahuddin (Universitas Negeri Yogyakarta) \\
\hline Secretariat
\end{tabular}




\begin{tabular}{|l|l|}
\hline Reviewers & $:$ Prof. Dr. H. Abd. Rahim Yunus, M.A. \\
$:$ Prof. Dr. H. Ahmad M. Sewang, M.Ag. \\
$:$ Prof. Dr. H. M. Dahlan M., M.Ag. \\
$:$ Prof. Dr. H. Hasaruddin, M.Ag. \\
$:$ Dr. Wahyuddin, G., M.Ag. \\
$:$ Dr. Susmihara, M.Pd. \\
$:$ Dr. Hj Syamzan Syukur, M.Ag. \\
$:$ Dr. Rahmawati, M.A. \\
$:$ Dr. Abu Haif, M.Hum. \\
$:$ Dr. Nasruddin, M.M. \\
$:$ Dr. Abd. Rahman Hamid. (UNHAS) \\
$:$ Dr. Nurhayati Syairuddin, M.Hum. \\
(UNHAS) \\
$:$ St. Junaeda, S.Ag., M.Pd., M.A. (UNM) \\
$:$ Nasihin, S.S., M.A. (UNM) \\
$:$ Ahmad Abbas Musofa (IAIN BENGKULU) \\
$:$ Arafah Pramasto (Dinas Sosial Kota \\
Palembanga)
\end{tabular}

Alamat Redaksi dan Tata Usaha : Jurusan Sejarah dan Kebudayaan Islam Fakultas Adab dan Humaniora UIN Alauddin Makassar, Jln. Sultan Alauddin No. 36 Samata Gowa Tlp. 0411-841879 Fax.0411-822140 (Kampus II) E.Mail. rihlah@uin-alauddin.ac.id

Jurnal Rihlah terbit dua kali dalam setahun, bulan Juni dan bulan Desember berisi kajian tentang Sejarah dan Kebudayaan, baik dari hasil penelitian maupun tulisan ilmiah lainnya.

Penyunting menerima tulisan yang belum pernah diterbitkan oleh media cetak lain. Naskah diketik spasi $1 \mathrm{~cm}$ pada kertas berukuran A4 dengan tulisan berkisar 10-23 halaman. Naskah yang masuk dievaluasi oleh Dewan Penyunting. Penyunting dapat melakukan perubahan pada tulisan yang dimuat untuk keseragaman format, tanpa mengubah maksud dan konten tulisan. 


\section{DAFTAR ISI}

Suryanti, Ihsan Mz, ST. Rahmah

$100-112$

Sejarah Diaspora Suku Bugis-Makassar di Kalimantan Tengah

Muhammad Husni.

$113-133$

Kearifan Lokal Handep Masyarakat Dayak: Perspektif Cendekiawan

Muslim Dayak di IAIN Palangka Raya

Aliyas, Benny Agusti Putra....

$134-144$

Tradisi Masyarakat Islam Melayu Jambi: Perspektif Pierre Bordieau

Nurannisa, Ahmad M. Sewang, Wahyuddin $G$

$145-156$

Tradisi Mappande Sasi' pada Masyarakat Tangnga-tangnga

Kabupaten Polewali Mandar (Unsur Budaya Islam)

Mastanning, Khadijah Tahir, Abdullah Renre

$157-175$

Implementasi Ritual Addinging-dinging pada Masyarakat Modern

di Tambung Batua Gowa: Tinjauan Sosio-Kultural

Faiz Nasrullah

$176-187$

Iran pada Masa Reza Syah 1925-1941

Muhammad $\mathcal{N}$ ur Ichsan Azis, Salmin Djakaria

$188-200$

Penyebaran Pendidikan Islam di Buol Abad XX M. 


\title{
Sejarah Diaspora Suku Bugis-Makassar di Kalimantan Tengah
}

\author{
Suryanti, Ihsan Mz, ST. Rahmah \\ Institut Agama Islam Negeri Palangka Raya \\ suryanti@iain-palangkaraya.ac.id \\ ihsan.mz@iain-palangkaraya.ac.id \\ sitirahmah16@gmail.com
}

\begin{abstract}
The presence of the Buginese-Makassarnese in Indonesia is always interesting when examined from various points of view, especially since this tribe has spread to various regions in the country and even abroad. The BugineseMakassarnese who settled in Central Kalimantan is interesting to study because their existence still shows a strong enggagement to the traditions of their origin. For example, the Buginese-Makassarnese who live in Central Kalimantan still maintain some of their ancestral traditions. Second, this community can also establish a harmonious and peaceful relationship with the Dayak people as the original inhabitant of Central Kalimantan, including other migrant communities from Java, Sumatra, and others. This type of research is qualitative with narrative study approach. Data collection techniques using in-depth interview and observation. The results of this study reveal that the reason of the Buginese-Makassarnese commit diaspora are due to conflict in their hometown and economic motives. For the BugineseMakassarnese, "Siri" is their soul and self-esteem, culture of noble values as an impetus to settle down and be successful overseas. This confirms that cultural roots and local wisdom should be preserved as a form of heritage.
\end{abstract}

Keywords: Buginese-Makassarnese; Central Kalimantan; Diaspora; History

Abstrak

Kehadiran suku Bugis-Makassar yang ada di Indonesia selalu menarik jika dikaji dari berbagai sudut pandang apalagi karena suku ini telah berdiaspora ke berbagai wilayah di tanah air bahkan mancanegara. Suku BugisMakassar yang menetap di Kalimantan Tengah menarik untuk dikaji karena keberadaan mereka masih menunjukkan keterikatan yang kuat dengan tradisi yang terdapat di daerah asal. Sebagai contoh, suku BugisMakassar yang tinggal di Kalimantan Tengah masih memelihara beberapa adat istiadat serta tradisi nenek moyang. Kedua, komunitas ini juga dapat menjalin hubungan yang harmonis dan damai dengan masyarakat Dayak yang merupakan penduduk asli Kalimantan Tengah, termasuk masyarakat perantau lainnya yang berasal dari Pulau Jawa, Sumatera, dan lain-lain. Jenis penelitian ini adalah kualitatif dengan pendekatan studi naratif. 
Teknik pengumpulan data menggunakan wawancara mendalam dan observasi. Hasil penelitian ini mengungkap bahwa penyebab suku BugisMakassar melakukan diaspora karena adanya konflik di kampung halaman, motif ekonomi dalam upaya mencari peruntungan. Bagi masyarakat BugisMakassar, "Siri" merupakan jiwa dan harga diri mereka, budaya nilai-nilai luhur sebagai pendorong bisa menetap dan sukses di tempat rantauan. Hal ini menegaskan bahwa akar budaya dan kearifan lokal seharusnya terus dijaga sebagai bentuk warisan para leluhur dimanapun berada.

Kata Kunci: Diaspora; Kalimantan Tengah; Sejarah; Suku BugisMakassar

\section{Pendahuluan}

Orang-orang yang melakukan diaspora atas keinginan sendiri atau dipaksa oleh keadaan, mereka bermukim di suatu daerah atau beberapa tempat lain, melakukan penjagaan terhadap identitas, menjalin hubungan baik dengan masyarakat setempat sehingga dapat terjalin hubungan antara kelompok tertentu. Diaspora tentu tidak dapat dilepaskan dengan migrasi manusia (human migration). ${ }^{1}$ Terjadinya diaspora sangat mewarnai proses pembentukan identitas di tempat yang baru di luar negara asalnya. Migrasi dan diaspora merupakan susunan identitas yang saling berkaitan sehingga menjadi bagian penting dalam struktur sosial pada komunitas etnik di berbagai negara. ${ }^{2}$

Beberapa penelitian sejarah telah menginformasikan tentang kelompok manusia-dalam hal ini Suku-yang dikenal memiliki tradisi diaspora (merantau). Di Indonesia, selain masyarakat Minang, suku Bugis-Makassar juga dikenal sebagai masyarakat perantau sebab mereka punya akar sejarah sebagai pelaut-pelaut yang tangguh.

Masyarakat suku Bugis-Makassar merupakan masyarakat yang berada di Provinsi Sulawesi Selatan. Masyarakat Bugis terdapat di beberapa Kabupaten seperti Pinrang, Bone, Luwu, Wajo, Barru, Sidrap dan Soppeng. Sedangkan daerah peralihan antara Bugis dan Makassar banyak ditemukan di Kabupaten Maros, Pangkajene Kepulauan, Sinjai dan Bulukumba. Daerah peralihan Bugis dan Mandar ada di Kabupaten Polman dan Pinrang bahkan suku Bugis-Makassar menyebar pula di propinsi Sulawesi Tenggara, Sulawesi Tengah, Papua, Kalimantan Timur, Kalimantan Selatan, Kalimantan Tengah bahkan mancanegara. ${ }^{3}$

Suku Bugis-Makassar memiliki nilai budaya yang meliputi unsur kebudayaan yang terdiri dari bahasa, sistem ekonomi/mata pencaharian, organisasi sosial,

${ }^{1}$ Iman Santoso, Diaspora, Globalisasi, Keamanan, dan Keimigrasian (Pustaka Reka Cipta, 2014).

${ }^{2}$ Hana Naufanita, Raden Maisa Yudono, dan Ani Soetjipto, “Analisis Wacana Diaspora Indonesia: Tinjauan Konseptual Dalam Hubungan Internasional," Jurnal Kajian Wilayah 9, no. 2 (28 Desember 2018): 90-108, https://doi.org/10.14203/jkw.v9i2.796.

3 Kaspin Rasyid, "Adat Dan Kebudayaan Suku Bugis," diakses 3 September 2020, https://www.academia.edu/7891105/Adat_dan_Kebudayaan_Suku_Bugis. 
kepercayaan, seni, sistem moral, adat, dan kemampuan serta kebiasaan yang dimiliki sebagai anggota masyarakat suku Bugis-Makassar. Seperti halnya masyarakat Suku Bugis-Makassar dikenal dengan suku perantau yang tersebar di beberapa wilayah di Indonesia bahkan sampai ke luar negeri. Penyebaran orang-orang suku BugisMakassar di luar Sulawesi Selatan disebabkan karena profesi dan mata pencaharian mereka yang umumnya sebagai nelayan dan pedagang sehingga memudahkan mereka untuk keluar mencari keuntungan perekonomian. Masyarakat Bugis-Makasar selalu berupaya mencari tempat yang dianggap layak bagi dirinya di luar kampung halaman untuk didiami, tempat bekerja, dan bermasyarakat.

Perantau suku Bugis-Makassar didorong atas dasar budaya "Siri". Bagi masyarakat Bugis-Makassar, Siri adalah jiwa dan harga diri mereka. ${ }^{4}$ Selain atas dasar budaya nilai-nilai luhur sebagai pendorong melakukan perantauan, motif lain adalah kondisi sosial politik yang terjadi di kampung halaman yaitu ingin menghindari konflik dan didorong pula oleh sikap optimis untuk meraih kesuksesan yang lebih baik di tanah rantau. Hal ini dapat dibuktikan dari jumlah orang Bugis yang cukup signifikan di beberapa wilayah Nusantara dan luar negeri.

Berdasarkan wawancara yang dilakukan terhadap pengelola Museum Balla Lompoa, MT yang menuturkan bahwa perantau suku Bugis-Makassar juga ada yang ingin meraih prestise dan prestasi yang besar di tanah rantau. Sebagai contoh, mantan Wakil Presiden Jusuf Kalla yang melanglang buana meraih kesuksesan dengan tetap menanamkan budaya Siri. Orang Bugis-Makassar menganggap baik jika keluar dari kampung halaman menuju tanah rantau, lalu meraih prestasi dan kesuksesan kemudian dapat menjadi pelopor di tempat rantau. ${ }^{5}$

Suku Bugis-Makassar yang tinggal di Kalimantan Tengah masih memelihara beberapa adat istiadat serta tradisi nenek moyang. Seperti halnya budaya siri yang sangat melekat pada masyarakat Bugis-Makassar. Siri adalah jiwa dan harga diri mereka. Hal ini menunjukkan bahwa budaya dan adat istiadat harus tetap dipertahankan sebagai bentuk warisan dari nenek moyang suku Bugis-Makassar dimanapun berada. Mereka juga bisa menjalin komunitas yang harmonis dan damai dengan masyarakat penduduk asli di wilayah rantauan termasuk masyarakat Suku Dayak, Banjar, Pulau Jawa, Sumatera, dan masyarakat pendatang lainnya.

Meskipun demikian, bukan berarti komunitas suku Bugis-Makassar di Kalimantan Tengah ini bebas dari tantangan. Di antara bentuk tantangan tersebut adalah proses globalisasi kebudayaan lokal yang berciri lokal kedaerahan yang terancam oleh negara karena negara memiliki pretensi untuk menciptakan sebuah identitas kebudayaan yang berciri nasional. ${ }^{6}$ Padahal jika berkaca pada sejarah,

4 Abdul Rasjid dan Gunawan Restu, Makassar Sebagai Kota Maritim (Jakarta: Direktorat Jenderal Kebudayaan Departemen Pendidikan Nasional, 2000).

${ }^{5}$ Wawancara dengan MT, Asal Usul Suku Bugis-Makassar, 2020.

6 Andi Muhammad Akhmar, Burhanuddin Arafah, dan Wahyuddin Pardiman, "Strategi Budaya Orang Bugis Pagatan dalam Menjaga Identitas Ke-Bugis-an dalam Masyarakat Multikultur," Kapata Arkeologi, 25 Juli 2017, 73-82, https://doi.org/10.24832/kapata.v13i1.392. 
sebetulnya konsep kebudayaan Indonesia atau kebudayaan nasional tidak lain diasalkan pada kebudayaan lokal (daerah). Akan tetapi di masa orde baru kebudayaan lokal yang ada terpinggirkan dan termarginalkan baik disengaja ataupun tidak. Identitas nasional yang dibangun dapat menghilangkan karakter identitas lokal secara perlahan.

Tantangan lain yang tidak kalah serius adalah globalisasi. Hilangnya batas geografis dan semakin intensifnya interaksi antar-budaya memunculkan komunitaskomunitas sosial baru. Kelompok ini lahir karena inovasi teknologi yang semakin marak. Komunitas dalam sosial media seperti WhatsApp, Twitter, Facebook, dan komunitas lainnya mengancam generasi muda saat ini. Kearifan dan nilai-nilai lokal menghadapi tantangan. Mampukah generasi muda yang berpendidikan dan akrab dengan teknologi bisa tetap mempertahankan nilai-nilai dari kebudayaan lokal yang ada ataukah sebaliknya justru tergantikan dengan nilai-nilai baru masyarakat pasar bebas seperti saat ini. ${ }^{\text {? }}$

Berangkat dari uraian di atas, peneliti ingin mengupas lebih jauh mengenai proses kedatangan Suku Bugis-Makassar di Kalimantan selanjutnya ingin menelusuri lebih jauh bagaimana eksistensi komunitas Suku Bugis-Makassar yang berdiaspora di wilayah Kalimantan Tengah. Berdasarkan penelusuran peneliti, ada beberapa tulisan atau penelitian terdahulu yang mengangkat tema yang serupa. Sebagai contoh, artikel yang ditulis oleh Muhammad Zid dan Sofjan Sjaf yang berjudul "Sejarah Perkembangan Desa Bugis-Makassar di Sulawesi Selatan" yang dimuat dalam Jurnal Sejarah Lontar Vol. 6 No. 2 Tahun 2009.

Penelitian ini diawali dengan mengurai aspek politik, budaya dan ekonomi di Sulawesi Selatan. Hal ini dilakukan dengan mendasarkan pada asumsi bahwa kesejarahan orang Bugis-Makassar tidak dapat dilepaskan dari tiga aspek tersebut. Ketiga aspek itu juga dipotret dari tiga periodisasi yang berkaitan erat dengan peristiwa-peristiwa yang terjadi di Indonesia kemudian termanifestasi dalam lingkup lokal di daerah-daerah. Tiga periodisasi tersebut adalah Pra-Kolonial, Kolonial dan Pasca-Kolonial. Setelah menjelaskan semua itu, artikel ini kemudian mengupas tentang dinamika orang Bugis-Makassar yang dipecah ke dalam beberapa bahasan yaitu: Pertarungan antara elit Bugis dan Makassar, Arus Migrasi Keluar Sulawesi Selatan, dan Pemberontakan DI/TII. ${ }^{8}$

Penelitian selanjutnya adalah artikel yang ditulis oleh Mansyur dengan judul "Diaspora suku Bugis dan terbentuknya identitas To-Ugi' di wilayah tanah Bumbu" yang dimuat dalam artikel Jurnal Sejarah Citra Lekha, vol. XVI, No. 2 Agustus 2011. Artikel ini memuat tentang Faktor utama yang mendorong terbentuknya

\footnotetext{
7 Akhmar, Arafah, dan Pardiman.

${ }^{8}$ Muhammad Zid dan Sofjan Sjaf, "Sejarah Perkembangan Desa Bugis - Makassar Sulawesi Selatan," Jurnal Sejarah Lontar 6, no. 2 (2009): 38-53.
} 
identitas suku Bugis ke wilayah Tanah Bumbu. Penelitian ini menggunakan kajian sejarah untuk mengetahui perkembangan diaspora yang dilakukan oleh suku bugis. ${ }^{9}$

Beberapa literatur penelitian terdahulu belum ditemukan tulisan yang membahas secara khusus tentang Diaspora Suku Bugis-Makassar Di Provinsi Kalimantan Tengah. Penelitian ini dilakukan untuk menambah informasi tentang penelitian masyarakat Bugis-Makassar yang merantau dan keluar dari tanah kelahiran. Menggunakan metode penelitian kualitatif yang menggunakan wawancara dan observasi sebagai teknik pengumpulan data, penelitian ini ingin mengurai proses dan sejarah masyarakat Bugis-Makassar merantau ke Kalimantan Tengah dan faktorfaktor yang menyebabkan mereka berdiaspora.

\section{Kedatangan Suku Bugis-Makassar di Kalimantan Tengah}

Secara geografis Provinsi Kalimantan Tengah terletak antara $0^{\circ} 45^{\prime} \mathrm{LU}-3^{\circ} 30^{\prime} \mathrm{LS}$ dan $110^{\circ} 45^{\prime}-115^{\circ} 51^{\prime} \mathrm{BT}$. Terdapat tiga provinsi yang mengapitnya, yaitu provinsi Kalimantan Selatan, Kalimantan Timur dan Kalimantan Barat. Luas wilayah Kalimantan Tengah sebesar $153.564 \mathrm{~km}^{2}$ atau 8,04 persen dari total luas daratan Indonesia. Ada sebelas sungai besar dan kurang lebih 33 sungai kecil. Keberadaan sungai-sungai ini merupakan ciri khas Kalimantan Tengah. ${ }^{10}$

Penduduk lokal yang mendiami pulau Kalimantan dikenal dengan sebutan Suku Dayak. Secara administratif, Pulau Kalimantan terbagi menjadi beberapa wilayah yaitu: Kalimantan Timur ibu kotanya Samarinda, Kalimantan Selatan dengan ibu kota Banjarmasin, Kalimantan Tengah dengan ibu kota Palangka Raya, Kalimantan Barat ibu kotanya Pontianak, dan Kalimantan Utara Ibu kotanya Tanjung Selor, yang bahasa dan pola hidup mereka berbeda antara satu wilayah dengan wilayah yang lain. Suku Dayak merupakan penduduk asli pulau Kalimantan. Sebagian besar orang Dayak mendiami pedalaman dengan hutan-hutan yang masih lebat serta di sepanjang tepi aliran sungai-sungai besar. ${ }^{11}$

Suku Bugis-Makassar yang terbiasa dengan tradisi merantau, juga menjadikan provinsi Kalimantan Tengah sebagai salah satu destinasi. Sebut saja di wilayah Kotawaringin Barat, Kotawaringin Timur, Kapuas, Seruyan, Barito Selatan, dan kota Palangka Raya adalah beberapa tempat yang didiami oleh masyarakat Bugis-Makassar. Bahkan di Kabupaten Seruyan terdapat kampung Bugis yang dihuni para perantau dari Sulawesi Selatan. Salah satu desa di Seruyan terdiri dari 90\% orang BugisMakassar.

Istilah diaspora dalam bahasa Bugis-Makassar dikenal dengan sebutan "Pasommpe" yang berasal dari kata "Sompe" yang berarti berlayar dengan awalan "Pa"

\footnotetext{
${ }^{9}$ Mansyur, "Diaspora Suku Bugis Dan Terbentuknya Identitas To-Ugi’ Di Wilayah Tanah Bumbu, Residensi Borneo Bagian Selatan Dan Timur, Tahun 1900-1942,” Citra Lekha 15, no. 2 (2 September 2011): 67-82.

10 Bob Setiabudi, Kalimantan Tengah Dalam Angka 2010 (Kalimantan Tengah: BPS Provinsi Kalimantan Tengah, 2012).

${ }^{11}$ Hamid Darmadi, "Dayak: Asal-Usul dan Penyebarannya di Bumi Borneo," Sosial Horizon: Jurnal Pendidikan Sosial 3, no. 2 (2016): 19.
} 
sebagai pelaku dari orang yang melakukan aktivitas pelayaran dari pulau ke pulau, atau dari satu negara ke negara lainnya. ${ }^{12}$ Dengan demikian, diaspora suku BugisMakassar yang tersebar di beberapa wilayah diperkirakan sudah berlangsung sejak berabad-abad lalu di wilayah nusantara seperti di Semenanjung Melayu yaitu di negara Malaysia, Riau, dan Kerajaan Johor. Sedangkan di bagian timur Indonesia berada di daerah Ambon, Kalimantan, dan Gorontalo. Didasari semangat merantau (Masomppe) dari beberapa penyebarannya tersebut suku Bugis mengembangkan perdagangan dan perikanan. Khusus di daerah Kalimantan, mereka mengembangkan bidang pertanian dan membuka lahan perkebunan. ${ }^{13}$

Sumber mata pencaharian masyarakat suku Bugis-Makassar umumnya berasal dari sumber daya alam dalam bidang pertanian, peternakan, dan kehutanan. Sedangkan potensi laut diperoleh dari bidang perikanan, tambak pelayaran dan perdagangan antar pulau. Aktivitas masyarakat di wilayah pesisir laut memiliki peranan dalam pelayaran dan perdagangan. Mereka dikenal sebagai pelaut yang sering merantau dan menyebar ke seluruh Indonesia.

Menurut catatan orang-orang Eropa yang datang ke Nusantara, Josef Conradyang telah melakukan lima kali pelayaran pada tahun $1887 \mathrm{M}$ antara Singapura dan Kalimantan Timur, Banjarmasin, Balikpapan, Pulau Laut dan Sulawesi Baratmencatat tentang keberadaan orang-orang Bugis di pelabuhan-pelabuhan yang dimasukinya dari Singapura sampai Bulungan karena menurutnya orang-orang Bugis dapat ditemukan dimanapun di wilayah Nusantara dan Malaya. ${ }^{14}$ Menurut Mattulada dalam bukunya menyatakan bahwa masyarakat suku Bugis-Makassar yang melakukan diaspora di segala penjuru Nusantara sejak abad XVI itu didasari atas terjadinya hubungan niaga antar bandar-bandar niaga di pulau Jawa, Sumatera, dan Malaka di kawasan barat dan kepulauan Maluku di kawasan timur. ${ }^{15}$

Pada dasarnya kehidupan masyarakat suku Bugis-Makassar sebagian dimensinya adalah pelaut dengan transportasi yang digunaka bukan udara dan bukan juga darat akan tetapi menggunakan jalur laut yang didasari pemahaman bahwa untuk meraih prestise dan prestasi, maka dapat ditempuh dengan cara keluar dari kampung halaman menuju perantauan lalu menjadi lebih baik di tanah rantau kemudian menjadi pelopor. Awalnya para perantau suku Bugis-Makassar kebanyakan bermukim di daerah pesisir pantai hingga kemudian masuk ke kota dan tempattempat lain. Menurut salah satu anggota keluarga seorang perantau di Makassar, inisial J, mengatakan bahwa ketika melakukan pelayaran, pada mulanya mereka tidak

12 M. Irfan Mahmud, "Pelayaran Dan Perdagangan Abad XVII-XIX Bugis-Makassar Ke Papua," Jurnal Penelitian Arkeologi Papua Dan Papua Barat 5, no. 1 (2013): 37-57.

${ }^{13}$ Andi Faisal Bakti, ed., Diaspora Bugis di Alam Melayu Nusantara, Cet. 1 (Makassar: Ininnawa, 2010).

${ }^{14}$ Philip O. L. Tobing, Hukum Pelayaran dan Perdagangan Amanna Gappa: Pembahasan Philologis, Kulturil (Yayasan Kebudayaan Sulawesi Selatan, 1977).

15 Mattulada, Menyusuri Jejak Kehadiran Makassar Dalam Sejarah, 1510-1700, Cet. 2., ed. rev. (Ujung Pandang: Hasanuddin University Press, 1991). 
memilih wilayah yang didatangi. Mereka hanya mengandalkan arah angin laut. Dimanapun mereka diarahkan oleh laut yang dinamis, maka di tempat itulah mereka menetap. Mula-mula mereka tidak punya pilihan daerah tertentu yang harus didatangi. Prinsip perantau suku Bugis-Makassar adalah menggunakan potensi yang dimiliki untuk meraih kehidupan yang lebih mapan. ${ }^{16}$ Masyarakat Bugis-Makassar dikenal sebagai pelaut ulung yang mengarungi lautan dengan mengandalkan alat transportasi perahu Pinisi.

Jika menilik sejarah lebih jauh ke belakang, tradisi berlayar suku BugisMakassar tidak lepas dari pelabuhan yang menjadi titik tolak keberangkatan atau sebagai tempat menambatkan perahu-perahu atau alat transportasi laut lainnya. Beberapa pelabuhan terkenal saat itu adalah Pelabuhan Somba Opu yang merupakan pusat perdagangan rempah-rempah. Pelabuhan ini sangat terbuka bagi siapapun yang ingin melakukan perdagangan. Hal tersebut menjadikan pelabuhan Somba Opu sangat ramai dikunjungi oleh kapal-kapal domestik maupun kapal dari berbagai belahan dunia seperti Spanyol, Inggris, Portugis, dan lain-lain. Pelabuhan Somba Opu berada di wilayah yang sangat strategis yaitu terletak antara Malaka dan Maluku yang menjadikan VOC (Verenigde Oost Indische Compagnie) atau Perkumpulan Dagang Hindia Timur ingin melakukan Monopoli dan mengusai Perdagangan di Makassar. ${ }^{17}$

VOC berusaha maksimal untuk menyediakan rempah-rempah bagi pasaran Eropa dengan cara memonopoli perdagangan rempah-rempah di Nusantara. Sementara bagi Kesultanan Makassar, kedatangan VOC merupakan ancaman atas kepentingan perdagangan dan pelayarannya di pulau Maluku. Terjadinya persaingan tersebut menimbulkan konflik sosial antara Kesultanan Makassar dengan VOC yang pada puncaknya terjadilah peperangan antara kedua belah pihak yang dikenal dengan Perang Makassar pada abad ke XVII. ${ }^{18}$ Konflik berlanjut pasca perjanjian Bongaya 18 Novemper 1668, yang menyebabkan terjadinya perubahan besar di kalangan kerajaan Bugis-Makassar. VOC mendapatkan monopoli dagang di Makassar dan semua orang Eropa non-Belanda dipaksa meninggalkan Makassar.

Konflik yang terjadi di Makassar mengakibatkan situasi keamanan tidak stabil. Maka terjadilah peningkatan diaspora orang orang Bugis-Makassar di tahun-tahun berikutnya ke berbagai wilayah. Pada abad ke-18 hingga abad ke-20 terdapat Pemukiman Bugis atau To-Ugi' di wilayah Kalimantan Tengah. Pemukiman yang dibangun orang-orang Bugis menjadi berkembang dalam jaringan bidang ekonomi.

16 Wawancara dengan J, Diaspora Suku Bugis-Makassar, 2020.

17 Johan Setiawan, Wakidi Wakidi, dan Yustina Sri Ekwandari, "Peranan Arung Palakka Dalam Perang Makassar Tahun 1660-1669," PESAGI (Jurnal Pendidikan Dan Penelitian Sejarah) 5, no. 3 (6 April 2017), http://jurnal.fkip.unila.ac.id/index.php/PES/article/view/12445.

18 Ahmad Yani, "Dampak Perang Makassar terhadap Umat Islam Sulawesi Selatan Abad XVII-XVIII M.," Riblab: Jurnal Sejarah dan Kebudayaan 6, no. 1 (26 Juli 2018): 107-31, https://doi.org/10.24252/rihlah.v6i01.5460. 
Mereka juga mengembangkan bidang perdagangan, pertanian, perkebunan dan perikanan. ${ }^{19}$

Berdasarkan uraian di atas, yang menjadikan masyarakat Bugis-Makassar lebih memilih melakukan Diaspora disebabkan: Pertama, untuk menghindari konflik yang terjadi. Menurut tradisi lisan dari orang-orang terdahulu, bahwa orang-orang bangsawan Bugis sudah mengetahui akan ada peperangan di daerah Makassar sehingga putra-putra mahkota tersebut diselamatkan dengan dibekali perahu, perlengkapan dan mengikutkan rakyatnya. Tujuannya adalah daerah yang pernah ditaklukkan oleh suku Bugis dan mempunyai hubungan diplomatik dengan kerajaan Bugis. Akan tetapi, tidak semua perahu dapat sampai ke tempat tujuan disebabkan mengikuti arah angin. Hal tersebut yang menjadikan mereka tersebar di beberapa daerah. ${ }^{20}$

Kedua, motif setelah era kemerdekaan lebih banyak disebabkan oleh motif ekonomi untuk mencari pekerjaan yang lebih baik. Seperti di wilayah Kalimantan Tengah, lebih kepada motif ekonomi atau penempatan kerja. Menurut salah satu warga pendatang suku Bugis di Kalimantan Tengah, inisial AB, mengatakan bahwa pada tahun 1980an, AB datang dengan mengendarai bis air dari Banjarmasin selama dua hari. Hal tersebut didorong oleh keinginan untuk memperbaiki kondisi ekonomi selain karena penempatan tugas. Menurut narasumber AB, pulau Kalimantan merupakan tempat paling strategis disinggahi para perantau dan aman untuk mengadu nasib.

Penduduk Kalimantan Tengah masih kurang jumlahnya dibandingkan kampung halaman (Sulawesi Selatan) dan wilayah lainnya seperti Surabaya dan Jakarta yang sudah banyak dihuni oleh pendatang dari berbagai daerah. Orang suku Bugis-Makassar tersebar di berbagai pulau di Kalimantan. Provinsi Kalimantan Tengah berada pada posisi terendah secara kuantitas dibandingkan provinsi Kalimantan lainnya. Akan tetapi, di Kalimantan Tengah terdapat kampung Bugis yang penghuninya $90 \%$ pendatang suku Bugis-Makassar. Berdasarkan sumbersumber informasi yang diperoleh secara lisan dari Komunitas KKSS (Keluarga Kerukunan Sulawesi Selatan) Provinsi Kalimantan Tengah, terdapat kampung Bugis di berbagai wilayah Kalimantan Tengah yang dihuni oleh pendatang suku BugisMakassar yang menganggap dirinya bagian dari masyarakat Kalimantan Tengah seperti di kota Sampit, Kabupaten Kotawaringin Barat, Kotawaringin Timur, Kapuas, Seruyan dan Buntok. ${ }^{21}$

Menurut hasil wawancara dengan salah satu ketua RT Kampung Bugis di wilayah Sampit Kecamatan Mentawai Ketapang Provinsi Kalimantan Tengah, mengatakan bahwa Kampung Bugis yang dihuni oleh masyarakat suku BugisMakassar berdiri pada abad ke-XVIII di Kabupaten Kotawaringin Timur, Kecamatan

Gramedia, 2003).

${ }^{19}$ Patrice Levang, Ayo ke Tanah Sabrang: Transmigrasi di Indonesia (Jakarta: Kepustakaan Populer

${ }^{20}$ Wawancara dengan Z, Latar Belakang Suku Bugis-Makassar Berdiaspora, 2020.

${ }^{21}$ Wawancara dengan AB, Diaspora Suku Bugis-Makassar di Kalimantan Tengah, 2020. 
Mentawai Baru, Desa Bapeang, Kalimantan Tengah. Masyarakat suku BugisMakassar yang datang ke Kalimantan Tengah pada abad XVIII saat itu menemui wilayah ini masih hutan belantara, tanah yang belum terawat dan tidak memiliki harga sehingga para pendatang suku Bugis melihat ada peluang bagus untuk mengolah tanah menjadi lahan pertanian dan perkebunan.

Mereka mengolah tanah yang dulunya hutan lalu dijadikan sebagai tempat tinggal. Melihat peluang ekonomi yang bagus di wilayah tersebut, para perantau suku Bugis-Makassar yang telah berada di kota Sampit Kalimantan Tengah memanggil keluarga mereka di kampung halaman untuk ikut memperbaiki nasib di tanah rantau. Proses ini yang kemudian menjadikan wilayah Kabupaten Kotawaringin Timur Kecamatan Mentawai Baru Desa Bapeang memiliki Kampung Bugis yang mayoritas penduduknya pendatang. Diperkirakan tahun 2020, terdapat 67 Kepala Keluarga suku Bugis-Makassar yang berprofesi dalam bidang pertanian, perkebunan dan perikanan.

Mengenai bahasa dan adat istiadat masyarakat Kampung Bugis di wilayah ini, sebagian masih menggunakan adat dan tradisi suku Bugis dalam acara pernikahan. Sedangkan mengenai bahasa yang digunakan sehari-hari di Kampung Bugis, masyarakat di sana masih melestarikan bahasa daerah (Bugis) ketika berkumpul dengan sesama perantau. Akan tetapi ketika di luar komunitas mereka, masyarakat Bugis-Makassar tetap menyesuaikan dengan bahasa lokal Kalimantan Tengah. ${ }^{22}$

\section{Perkembangan Eksistensi Suku Bugis-Makassar di Kalimantan Tengah.}

Keberadaan suku Bugis-Makassar di Kalimantan Tengah tidak dapat dipisahkan dari faktor ekonomi. Mereka rela meninggalkan tanah kelahiran demi perbaikan nasib dan mencari peruntungan di tanah rantau. Hampir setiap keluarga memiliki anggota keluarga yang melakukan perantauan atau diaspora. Tentu dalam memutuskan untuk merantau ke luar kampung halaman, harus ditopang dengan beberapa keahlian dasar yaitu:

1. Komunikasi. Kemampuan komunikasi antar sesama pendatang dan masyarakat setempat merupakan keterampilan dalam mengucapkan bahasa, dengan mengandalkan bahasa komunikasi yang baik dengan masyarakat setempat.

2. Pernikahan. Cara ini tidak lepas dari kemampuan komunikasi. Masyarakat setempat tentu sangat menghargai individu yang mampu berkomunikasi dengan baik meskipun pendatang. Pergaulan yang berlangsung dalam waktu lama akan berdampak pada penilaian diri antara individu yang sedang melakukan interaksi. Di sini muncul ketertarikan antara satu dengan yang lain kemudian terwujud dalam bentuk pernikahan dengan masyarakat setempat.

3. Keberanian. Menggunakan potensi fisik dengan menanamkan jati diri sebagai seorang suku Bugis-Makassar yang memiliki prinsip "Siri na Pesse" untuk mendapatkan posisi yang layak di tengah-tengah masyarakat. ${ }^{23}$

22 Wawancara dengan AF, Kampung Bugis di Kabupaten Kotawaringin Timur, 2020.

23 Bakti, Diaspora Bugis di Alam Melayu Nusantara. 
Ungkapan "Sekali layar berkembang pantang biduk surut ke pantai" dan "Siri na Passe" (harkat dan martabat) adalah 2 prinsip yang dipegang tegus oleh perantau suku Bugis-Makassar. Ada rasa malu dalam diri jika mereka tidak memperoleh kesuksesan. Mereka yang melakukan diaspora sejatinya telah menanamkan empat kesempurnaan dalam diri yaitu: berani, pintar, jujur dan modal. Lalu disempurnakan dengan ilmu agama. Perantau suku Bugis-Makassar juga dikenal sebagai masyarakat yang agamis.

Menurut MT, seorang budayawan mengatakan bahwa ketika ingin sukses di tempat rantau, maka yang harus dipahami adalah aspek daya pengetahuan kehidupan (Selupappa') yang penjelasannya sebagai berikut: 1) Tanah warnanya hitam mewakili sifat rendah hati, 2) Air warnanya putih bening yang mewakili kesucian, 3) Angin warnanya kuning yang berarti mulia, dan 4) Api berwarna merah yang berarti dinamis. Dalam gambaran kehidupan masyarakat, keempat warna ini sebagai model dalam berkomunikasi sesama manusia. Filosofi harmonisasi perilaku masyarakat Bugis-Makassar yaitu; Manusia harus harmonis dengan Maha Pencipta, Manusia harus harmonis antar sesama manusia, dan manusia harus harmonis dengan alam. ${ }^{24}$

Sehubungan dengan hal di atas, masyarakat Bugis-Makassar yang merantau ke Kalimantan Tengah jika mengalami keterpurukan, maka masyarakat lokal (suku Dayak) dengan tangan terbuka memberikan bantuan kepada para perantau. "Dasengnge Tomadecceng Weddi Natii Alena" yang artinya adalah ketika kamu berperilaku baik, maka kamu akan diperlakukan baik pula oleh orang lain. Narasumber AH mengungkap bahwa selama berada di Kalimantan Tengah, tidak pernah terjadi konflik antara suku Bugis-Makassar dengan masyarakat Dayak. Fakta ini membuktikan bahwa perantau Bugis-Makassar dapat beradaptasi dengan masyarakat setempat dan mengedepankan etika yang luhur. ${ }^{25}$

Masyarakat Bugis-Makassar yang melakukan diaspora ke berbagai wilayah bahkan ada yang menetap lebih lama hingga memiliki keturunan, menjadikan mereka berbaur dan melebur dengan masyarakat lokal dan lebih memilih mengikuti bahasa setempat. Hal ini dipicu oleh interaksi interpersonal dalam waktu yang lama, pernikahan dan perasaan yang nyaman dengan lingkungan setempat.

Menurut seorang Sejarawan yang melakukan penelitian tentang perantau suku Bugis-Makassar di berbagai wilayah mengungkap bahwa identitas masyarakat Bugis dapat diidentifikasi berdasarkan suku kata dalam nama seseorang seperti yang berawalan 'LA', misalnya: Laode, Lamarilau, Lamusu, Latjuba dan sebagainya. Dua contoh terakhir dimiliki oleh publik figur tanah air namun kemungkinan mereka adalah generasi ke-VII yang sudah tidak mengetahui bahasa dan budaya BugisMakassar yang disebabkan oleh akulturasi dengan masyarakat lokal. ${ }^{26}$

Proses kedatangan suku Bugis-Makassar ke Kalimantan Tengah masih terus berlangsung hingga sekarang. Ada yang datang dengan tujuan mencari nafkah,

\footnotetext{
${ }^{24}$ Wawancara dengan T, Asal Usul Suku Bugis-Makassar.

25 Wawancara dengan AH, Suku Bugis-Makassar di Palangka Raya, 2020.

${ }^{26}$ Wawancara dengan Z, Latar Belakang Suku Bugis-Makassar Berdiaspora.
} 
menghindari konflik di kampung halaman, dan ada pula yang sengaja ikut keluarga yang telah bermukim lebih dahulu di perantauan. Di Kota Palangka Raya, umumnya pendatang suku Bugis-Makassar tergabung dalam Kerukunan Keluarga Sulawesi Selatan (KKSS) Provinsi Kalimantan Tengah. Suku Bugis dikenal dimana-mana karena ulet bekerja, bisa berbaur dengan penduduk lokal. Tidak ada perantau suku Bugis-Makassar yang malas karena menerapkan siri, malu pulang kalau tidak mencapai sukses. Agar dapat meraih sukses harus berpikir kreatif dan berprestasi sehingga dapat dikenal dan harus berani memulai dari bawah. Harus memiliki banyak cara untuk meraih sukses.

Walaupun tidak bisa menjadi pimpinan, setidaknya dapat berpikir kreatif dan cerdas. Sebagian mereka telah sukses dan memilih menetap di Kalimantan Tengah. Diantaranya ada yang menjadi pelopor utama dalam perekonomian di bidang pertanian dan persawahan. Ada yang berprofesi sebagai kepala Kantor Wilayah Kementerian tertentu, tenaga pengajar, staf adminstrasi di Pemerintah Daerah kota Palangka Raya, dan sebagainya.

Mereka menjalin hubungan baik dengan masyarakat setempat melalui perkawinan, relasi kerja, persahabatan, dan hubungan sosial kemasyarakatan. Perantau Bugis-Makassar yang tergabung dalam KKSS umumnya masih bisa berbahasa daerah asal kecuali anak keturunan mereka yang lahir dan besar di tanah rantau. Ada yang berupaya untuk tetap mengajarkan kepada anak keturunan tradisi dan budaya nenek moyang dengan cara mudik (pulang kampung) secara berkala.

\section{Kesimpulan}

Suku Bugis-Makassar yang tersebar di beberapa wilayah diperkirakan sudah berlangsung sejak berabad-abad lalu di wilayah nusantara bahkan di Semenanjung Melayu seperti di Malaysia, Riau, dan Kerajaan Johor. Sedangkan dibagian timur Indonesia berada di daerah Ambon, Kalimantan, Gorontalo, didasari semangat merantau (Massompe). Beberapa penyebarannya tersebut suku Bugis mengembangkan perdagangan, perikanan, pertanian, dan pembukaan lahan perkebunan khususnya di daerah Kalimantan yang banyak didatangi oleh masyarakat suku Bugis-Makassar. Penyebaran Suku Bugis Makassar di berbagai wilayah luar Sulawesi Selatan disebabkan mata pencaharian orang-orang suku Bugis-Makassar umumnya merupakan nelayan dan pedagang. Masyarakat suku Bugis-Makassar keberadaanya di berbagai wilayah demi meraih kesuksesan dengan menanamkan Siri.

Pada umumnya pendatang suku Bugis-Makassar tergabung dalam Kerukunan Keluarga Sulawesi selatan (KKSS) dan sebagian besar mereka telah sukses dan menetap di Kalimantan Tengah. Mereka menjalin hubungan baik, bekerjasama dengan masyarakat setempat melalui perkawinan, relasi kerja, persahabatan, dan sesama tetangga. Mereka yang tergabung dalam KKSS bisa dikatakan masih bisa berbahasa daerah asalnya kecuali anak keturunan mereka yang lahir dan besar di tanah rantau yang tidak lagi mengenal bahasa daerah asalnya. 


\section{Daftar Pustaka}

Akhmar, Andi Muhammad, Burhanuddin Arafah, dan Wahyuddin Pardiman. "Strategi Budaya Orang Bugis Pagatan dalam Menjaga Identitas Ke-Bugis-an dalam Masyarakat Multikultur." Kapata Arkeologi, 25 Juli 2017, 73-82. https://doi.org/10.24832/kapata.v13i1.392.

B, A. Diaspora Suku Bugis-Makassar di Kalimantan Tengah, 2020.

Bakti, Andi Faisal, ed. Diaspora Bugis di Alam Melayu Nusantara. Cet. 1. Makassar: Ininnawa, 2010.

Darmadi, Hamid. "Dayak: Asal-Usul dan Penyebarannya di Bumi Borneo." Sosial Horizon: Jurnal Pendidikan Sosial 3, no. 2 (2016): 19.

F, A. Kampung Bugis di Kabupaten Kotawaringin Timur, 2020.

H, A. Suku Bugis-Makassar di Palangka Raya, 2020.

J. Diaspora Suku Bugis-Makassar, 2020.

Levang, Patrice. Ayo ke Tanah Sabrang: Transmigrasi di Indonesia. Jakarta: Kepustakaan Populer Gramedia, 2003.

Mahmud, M. Irfan. "Pelayaran Dan Perdagangan Abad XVII-XIX Bugis-Makassar Ke Papua." Jurnal Penelitian Arkeologi Papua Dan Papua Barat 5, no. 1 (2013): 37 57.

Mansyur. "Diaspora Suku Bugis Dan Terbentuknya Identitas To-Ugi' Di Wilayah Tanah Bumbu, Residensi Borneo Bagian Selatan Dan Timur, Tahun 19001942." Citra Lekha 15, no. 2 (2 September 2011): 67-82.

Mattulada. Menyusuri Jejak Kehadiran Makassar Dalam Sejarah, 1510-1700. Cet. 2., ed. Rev. Ujung Pandang: Hasanuddin University Press, 1991.

Naufanita, Hana, Raden Maisa Yudono, dan Ani Soetjipto. "Analisis Wacana Diaspora Indonesia: Tinjauan Konseptual Dalam Hubungan Internasional.” Jurnal Kajian Wilayah 9, no. 2 (28 Desember 2018): 90-108. https://doi.org/10.14203/jkw.v9i2.796.

Rasjid, Abdul, dan Gunawan Restu. Makassar Sebagai Kota Maritim. Jakarta: Direktorat Jenderal Kebudayaan Departemen Pendidikan Nasional, 2000.

Rasyid, Kaspin. "Adat Dan Kebudayaan Suku Bugis.” Diakses 3 September 2020. https://www.academia.edu/7891105/Adat_dan_Kebudayaan_Suku_Bugis.

Santoso, Iman. Diaspora, Globalisasi, Keamanan, dan Keimigrasian. Pustaka Reka Cipta, 2014.

Setiabudi, Bob. Kalimantan Tengah Dalam Angka 2010. Kalimantan Tengah: BPS Provinsi Kalimantan Tengah, 2012.

Setiawan, Johan, Wakidi Wakidi, dan Yustina Sri Ekwandari. "Peranan Arung Palakka Dalam Perang Makassar Tahun 1660-1669.” PESAGI (Jurnal Pendidikan Dan Penelitian Sejarah) 5, no. 3 (6 April 2017). http://jurnal.fkip.unila.ac.id/index.php/PES/article/view/12445.

T, M. Asal Usul Suku Bugis-Makassar, 2020. 
Tobing, Philip O. L. Hukum Pelayaran dan Perdagangan Amanna Gappa: Pembahasan Philologis, Kulturil. Yayasan Kebudayaan Sulawesi Selatan, 1977.

Yani, Ahmad. "Dampak Perang Makassar terhadap Umat Islam Sulawesi Selatan Abad XVII-XVIII M." Rihlah: Jurnal Sejarah dan Kebudayaan 6, no. 1 (26 Juli 2018): 107-31. https://doi.org/10.24252/rihlah.v6i01.5460.

Z. Latar Belakang Suku Bugis-Makassar Berdiaspora, 2020.

Zid, Muhammad, dan Sofjan Sjaf. "Sejarah Perkembangan Desa Bugis - Makassar Sulawesi Selatan.” Jurnal Sejarah Lontar 6, no. 2 (2009): 38-53. 